\title{
Are We Catering Our Students? Teacher Feedback and Student Preference in ELT
}

\author{
Siti Asmiyah \\ English Language Education Department \\ UIN Sunan Ampel \\ Surabaya, Indonesia \\ siti.asmiyah@uinsby.ac.id
}

\author{
Fitriah \\ English Language Education Department \\ UIN Sunan Ampel \\ Surabaya, Indonesia
}

\author{
Fajar Kresno Alwiyono \\ English Language Education Department \\ UIN Sunan Ampel \\ Surabaya, Indonesia
}

\begin{abstract}
Feedback in English Language Teaching has been believed to play a crucial role in the development of student English competency. This paper presents findings from observation, interview, and questionnaire and document analysis from speaking and writing classes in two Indonesian high schools. Different types of feedback used in these two different skills are presented along with teacher perspectives on their use of feedback and student preference on teacher feedback in these two skills. Findings indicate that while student prefer particular type of feedback, teacher view that student need certain type of feedback other than what student prefer. The paper also highlights the possible cause of such discrepancy.
\end{abstract}

Keywords : teacher feedback, student preference

\section{INTRODUCTION}

An important element in English Language Teaching (ELT), particularly in the English as a foreign language (EFL) context, is the use of feedback. This is because in every learning process, students may go through some confusion, trial and error and make mistakes in understanding and using English as a language that does not always function in their day to day communication. In such a case, feedback plays an important role in developing EFL student's English acquisition. Feedback facilitates student better understanding on the meaning and language construction[1], improve their language learning[2] and builds students' confidence[3]. This idea of the role of feedback in the development of students' language competence particularly that in EFL context, is also highlighted by Ellis in that feedback cannot only ensure students' language accuracy but also boost their motivation in language learning[4]. feedback assists students develop their writing skills and builds students' awareness of the readers[5] as well as developing better students' ability in speaking[6].
The significance of feedback is unavoidable, even in English as first language context, they still need feedback to develop their language acquisition as they are processing some elements of language they have not acquired[7]. Feedback on student writing can not only provide evaluation on the written product, inform the writers whether they have conveyed the message and gives students sense of readers[8]. In ELT in EFL context, feedback plays a stronger role as students may not be equipped with sufficient knowledge, skills and context of the language and language use. This important role of feedback is highlighted in a research finding on the effectiveness of indirect feedback to student's English writing[9]. Feedback in language learning has also invited interest of not only teachers but also practitioners and experts in ELT for decades. These studies have explored different areas of feedback such as source of feedback (self, peer and teacher feedback), the effectiveness of feedback on the development of student' oral and written production and student's response to feedback. Among the studies conducted in the area of feedback both in student oral and written production. Those of the former include findings that feedback improves student's accuracy, precision and comprehensibility in their use of language[10] and allows response and interaction[11].

An Indonesian study on oral feedback highlights that student reflected their being benefited from feedback because they can repair their utterances. Other studies in Indonesian context focusing on feedback in writing do not always have consistent findings. Some research findings signify the importance of feedback on the development of student writing[12] and effectiveness of indirect feedback to develop student procedure text better student achievement in writing after the use of peer feedback[13]. However, there is also a finding showing that feedback does not always lead to improvement in student ability. A finding indicates that given feedback by the teacher, student had better understanding but little improvement on the quality of the writing[14].

The aforementioned studies; however, tend to focus on one particular language production only. Also, there seems to 
be no thorough study yet on students' preference on the feedback. Therefore, an understanding of how teacher give feedback to the students and whether such feedback meet student's preference has not yet been conclusive. Hence a study on teacher feedback and student preference using the same English classroom context is deemed to be important to better understand the conformity between what is given by the teacher and what is preferred by the student. This paper presents findings a study on types of teacher feedback on student's English oral and written production and students' preference on the teacher feedback in Indonesian EFL context. More specifically, this study investigated whether the teachers tend to use the same type of feedback regardless of the skills students learning and whether there is any shared preference of feedback on students' English productive skills.

\section{ERRORS AND FEEDBACK IN ENGLISH LANGUAGE TEACHING}

Repair and revision have been claimed as central in the teaching of English. Repair and revision commonly come after feedback. In students' learning to speak English, feedback stimulate students' motivation and ensure accuracy in language use. Teacher's feedback, particularly in English writing, helps students evaluate if their message has been conveyed well, give them opportunity to rethink and revise their writing. Also, feedback can build students' awareness of the audience and view of others related to the text being developed.

\section{A. Types of Feedback}

Based on the source, feedback can be classified into selffeedback, peer feedback, and teacher feedback. Teacher feedback is provided by the teacher, peer feedback by their peer and self feedback by the students themselves.

Teacher feedback is believed to play central role not only in the development of students' writing but also to the grading system.Teacher feedback helps learners identify the strength and weakness in the production[15]. Peer feedback enable students not only to learn from each other but also develop their understanding on what is appropriate and which one is not[16]. Self feedback is feedback provided by the students themselves when they evaluate their own language production, weigh their own strength and weakness and improve their understanding[17]. Self feedback is a term commonly used in written production while in oral one it is generally referred as self repair. These three types of feedback are equally important in helping students recognize the quality of their production and the acceptability of such production by the reader or listener.

Seen from the comments given, feedback can be further classified into praise, criticism, advise or suggestion[18] and correction or corrective feedback[19]. Praise shows positive values, credits, approval, appreciation, even surprise and excitement[20]. Praise can not only develop students' self- esteem and motivation but also build closer teacher-student and student-student relationship. In contrast to praise, criticism is a kind of negative comment or disapproval[21] such as the term 'incorrect use of grammar'. Another feedback similar to criticism but focuses more on point for improvement is suggestion. A commentary such as 'it is better if ...' shows disapproval on a particular point but at the same time provides alternative for revision and improvement. The other feedback that commonly focuses more on language form and structure is corrective feedback[22]. This corrective feedback can be further categorized into explicit correction, recast, clarification request, metalinguistic feedback, elicitation and repetition[23].

\section{B. Feedback and Student Preference}

While the commonly believed on the benefit of feedback in ELT have been supported by majority of studies on feedback, there has been few literature exploring how students' perspective and preference on feedback influence their language learning and development of their skills. The study presented in this paper did not measure the correlation of such preference and students 'ability, a short review on the position of students' perception and preference on feedback is worth doing. Such a review will enable any further reflection and discussion on the fulfillment of student's need and expectation on feedback in their language learning.

Repair in oral production and revision in written production may be well influenced by feedback, be it form student's self evaluation, from their peer or from the teacher. Hence, study on student preference is deemed to be important[24], [25]. Research on student preference on feedback for their writing shows that students prefer to have suggestion[26]. It is worth nothing that finding on student preference does not show conformity between teacher use of feedback and student preference[27], [28], [29].

\section{RESEARCH METHOD}

To get data on types of feedback used by Indonesian ELT teachers, data were collected from two senior high schools in Indonesia, one state school in Sidoarjo and the other one in Lamongan. Both schools are reputable and nationally accredited A (excellent). Twenty nine students in the school in Lamongan and 128 students in the school in Sidoarjo participated in the research. There were different data on collected from these two cohorts of participant. The teacher and students in Lamongan were the source of data for feedback in students' English oral production while the ones in Sidoarjo were for written production. Hence, a larger number of respondents could participate as the written feedback were well recorded on students work while oral feedback must be collected through recording. Thus, data collection with large number of students was not feasible.

Oral feedback in speaking was collected through two classroom-observations and recording. Observation in speaking class recorded student's English utterances during 
classroom activities and teacher's feedback to student. The utterances and the feedback were transcribed, identified and categorized based on the types. In the writing class, students' English writing which have been given feedback by the teachers were collected. The errors and the feedback were coded and tabulated based on the types. The teacher was interviewed to explore teacher class while the other one was on writing class. The teachers were interviewed to explore their consideration in the selection of feedback. Seven students with the errors during their oral production were interviewed. The interview responses were transcribed, coded and their preference on teacher's feedback were identified. For feedback on oral productions, all students' writing in English were collected, any feedback from the teacher were identified, tabulated and categorized based on the type. Questionnaire was distributed to all 158 students to investigate their preferences of the types of feedback given by their English teachers. Student's responses were collected and categorized and put into percentages based on the option they selected on each question. The percentage shows student most preferred to the least preferred type of feedback.

\section{FINDINGS AND DISCUSSION}

\section{A. Students' Error and Teacher Feedback}

Classroom observation, close reading, interview and questionnaire highlight the following findings on the type of errors given feedback by the teacher, type of feedback and students preference on the feedback. Data from two observation in English speaking class shows the following feedback by the teacher. Findings from this study on teachers' feedback and students' preference on feedback to further evaluate if the teachers have catered students' need and preference in terms of feedback for development of their English productive skills are presented below:

TABLE I.

STUDENT,S OF ERRORS AND TEACHER FEEDBACK IN ORAL PRODUCTION

\begin{tabular}{|c|l|l|}
\hline No & \multicolumn{1}{|c|}{$\begin{array}{c}\text { Types of errors given } \\
\text { feedback }\end{array}$} & \multicolumn{1}{c|}{ Feedback } \\
\hline 1 & $\begin{array}{l}\text { Grammatical errors (tenses, } \\
\text { pronoun, verb form, article): } \\
18 \text { utterances }\end{array}$ & $\begin{array}{l}\text { Example 1: } \\
\text { S: You will confuse } \\
\text { T: You will confuse or } \\
\text { you will be confused } \\
\text { S: You will be confused } \\
\text { T: Why? } \\
\end{array}$ \\
& $\begin{array}{l}\text { Example 2: } \\
\text { S: Where are you com } \\
\text { from? }\end{array}$ \\
& & \\
& & \\
& &
\end{tabular}

\begin{tabular}{|c|c|c|}
\hline & & $\begin{array}{l}\text { from? } \\
\text { S: Eh, yes. Where do } \\
\text { you come from? }\end{array}$ \\
\hline 2 & $\begin{array}{l}\text { Phonological errors: } 12 \\
\text { utterances }\end{array}$ & $\begin{array}{l}\text { S: Respect your } \\
\text { 'en'viranmənt, okay! } \\
\text { T: Respect your? } \\
\text { S: In'vaIrənmənt? } \\
\text { Respect your } \\
\text { In'vairənmənt, okay! }\end{array}$ \\
\hline 3 & $\begin{array}{l}\text { Lexical error (wrong word } \\
\text { choice, word formation, } \\
\text { collocation, literal } \\
\text { translation, omission or } \\
\text { incompletion): } 9 \text { utterances }\end{array}$ & $\begin{array}{l}\text { Example 1: } \\
\text { S: ... and solution... } \\
\text { one... two } \\
\text { T: ... and the solutions } \\
\text { are, first, second, third. } \\
\text { Not... and solution one } \\
\text { no }\end{array}$ \\
\hline
\end{tabular}

Findings on the type of students' errors in their oral production which are given feedback by the teacher shows that students' errors that become the main concern of the teachers is grammatical errors. This may be because students still find English grammar confusing. Such confusion was also found a previous study[30]. The types of grammatical errors produced by the students also reflect findings from previous studies that students mostly make grammatical, pronunciation, lexical and semantic errors[31] with grammatical errors being the most often corrected. The second most-given-feedback errors in oral production are pronunciation errors. Such students' inaccuracy in pronunciation may be due to different phonological system between Melayu language (including Bahasa Indonesia and Malaysian Melayu) and English[33]. The last type of students' error, the lexical errors, may serve as an indication of their level of second language vocabulary acquisition[33]. The wrong word choice, wrong use of word and the literal translation of such as 'this is the last from us' (translated from [materi] yang terakhir dari kami) may show that there is still very strong influence of their first language.

Grammatical error being the most given feedback in students' English oral production is also highlighted in feedback on students' English writing. The findings show that the teacher mostly commented the incorrect use of grammar such as in the following table.

TABLE II.

STUDENTS' ERROR AND TEACHER FEEDBACK IN WRITTEN PRODUCTION

\section{\begin{tabular}{|l|c|c|}
\hline No & Types of errors & Example of feedback \\
\hline
\end{tabular}}


The excerpt shows that the teacher used recast to correct

\begin{tabular}{|c|c|c|}
\hline 1 & Grammatical errors & $\begin{array}{l}\text { a. Wrong grammar } \\
\text { b. Incorrect grammar } \\
\text { c. You should check the verb } \\
\text { d. Please check the grammar } \\
\text { e. Add to be } \\
\text { f. It should be 'it is' } \\
\text { g. It should be plural, add -s } \\
\text { h. Delete the -s } \\
\text { i. This sentence should not } \\
\text { use to be }\end{array}$ \\
\hline 2 & Development & $\begin{array}{l}\text { You should describe the guitar } \\
\text { more specific }\end{array}$ \\
\hline 3 & Organization & Don't separate the paragraph \\
\hline 4 & Lexical item & $\begin{array}{l}\text { You should use simple word } \\
\text { to make it easy to understand }\end{array}$ \\
\hline 5 & Sentence structure & $\begin{array}{l}\text { a. Wrong sentence } \\
\text { b. This sentence is unclear } \\
\text { c. Confusing sentence }\end{array}$ \\
\hline 6 & Mechanic & $\begin{array}{l}\text { It is better if you use ... } \\
\text { Punctuation }\end{array}$ \\
\hline
\end{tabular}

Data on teachers' feedback on students' writing shows that the highest number of feedback is on students' grammatical errors. This indicates two things: that students may have high number of errors in terms of the grammar used in their writing and that the teacher may focus more on grammatical errors rather than on other points of good writing.

Data on teachers' feedback to students speaking shows that the teachers mainly used corrective feedback. Such feedback can be further categorized into four namely explicit correction, metalinguistic feedback, recast and elicitation. For the English writing, the teachers use four types of feedback, namely praise, criticism, suggestion and corrective feedback. Discussion of each of these types of feedback is presented below.

The first type of feedback given by the teacher is recast. In recast, the teacher implicitly gave the correct production by repeating the wrong expression in the correct form. The following excerpt shows this use of recast.

\section{$\mathrm{S}$ : Where are you come from?}

\section{T: Where do you come from?}

S: Eh ...yes, where do you come from? student's grammatical error.

Another type of feedback is explicit feedback as can be seen in the following excerpt.

$\mathrm{S}$ : and solution ....one...... two

$\mathrm{T}$ : and the solutions are, first, second, third Not...And solution one no

In the excerpt the student made mistake on the use of ordinal number and the teacher directly gave the correct form. This shows that the teacher used explicit correction feedback. Teacher response to an interview related to the use of such explicit correction feedback indicates that the teacher selected this type of feedback because it saves time. This finding is different from that of [34] in that recast was the highest in the frequency of the type of feedback used in students' oral production.

The second type of oral feedback used by the teacher is metalinguistic feedback. This can be seen from the following excerpt.

\section{S: You will confuse}

T: you will confuse or you will be confused?

S: you will be confused

$\mathrm{T}:$ Why?

Different from explicit correction presented earlier, this excerpt shows that the teacher assisted students to be aware of their own mistakes and self correct. When asking 'you will confuse or you will be confused?' the teacher stimulated student's understanding on their error and when asking 'why' the teacher gave student opportunity to recall on student's linguistic knowledge.

The other type of feedback used by the teacher is elicitation; that is, the teacher elicited the right way of saying by repeating the student's phonological error and pausing to enable student repeat the production with the correct one. This is reflected in the following excerpt.

S: respect your 'en'viranmont okay!

$\mathrm{T}:$ respect your?

S: In 'vairanmənt? respect your In 'vairənmənt okay!

The elicitation as reflected in the above excerpt shows that this type of feedback was used by the teacher to student's error in pronunciation. While in oral production the teacher used corrective feedback, the types of feedback in written production show more varieties. In addition to corrective feedback, the teacher also used suggestion and criticism in responding to students' error in their English writing. 
Referring back to data on Table II, the feedback of 'wrong grammar', 'incorrect grammar', 'wrong sentence', 'this sentence is unclear' and 'confusing sentence' shows teacher's criticism. Such comments show teacher's dissatisfaction to elements of students' work. The data show that this criticism is used by the teacher to give feedback related to students' error in the use of grammar and inappropriate structure of student's sentence.

The second type of feedback used by the teacher is suggestion. This can be seen from comments such as 'you should check the verb', 'please check the grammar', 'you should describe the guitar more specific', 'it is better if you use ... punctuation ', 'don't separate the paragraph', 'you should use simple word to make it easy to understand'. These expressions show what accomplishable action students can do to improve their English writing. The data show that the teacher used this suggestion as feedback in all elements of students' writing.

The other type of feedback used by the teacher is corrective feedback, that is feedback that is aimed to student acquire the correct linguistic forms and structures. When the teacher wrote 'add to be', 'it should be 'it is', 'add -s', 'delete the $-s$ ' the students were directly given the right form. Teacher's corrective feedback show that such correction mainly was used to grammatical errors.

This finding on the types of feedback used by the teacher in response to students' errors in English writing confirm previous findings on the use of criticism, suggestion and correction as feedback to student's written production. Findings on the types of feedback used by the teachers both in students' English speaking and writing highlight that the teacher mainly focus on correcting the grammatical errors. Table I and table II both show the high frequency of feedback given to grammatical errors. This confirms that students commonly are confused with English grammatical rules and findings that teacher mainly focus on correcting students' incorrect use of grammar.

\section{B. Students' Preference on Feedback}

Understanding whatstudents prefer related to their learning is important. So, teacher should understand what and how student want to learn. Exploration on students' preference related to teacher's feedback highlights that for English speaking, students in majority are evenly divided between metalinguistic feedback (89\%) and explicit correction (82\%). They also like to be given elicitation (72\%); however, they seem to disfavor recast as only $38 \%$ students selected the option of recast as their feedback preference. Result from student interview shows that students' preference to metalinguistic feedback is because such type of feedback enables them to 'think by [themselves] about the error and activate [their] knowledge and generate [their] thinking to discover the correct form'.
While they reflected that they prefer metalinguistic feedback, their other response indicates that they seem to feel unconfident and insecure to repair their own errors in speaking. This is indicated by relatively equal high frequency of response to preference to explicit correction (82\%). In explicit correction, the teacher clearly indicates students' incorrect form of language use [38]. The students reflected that when given explicit correction they can be sure what the correct form is by referring to the teacher explanation. These preferences between wanting to be given chance to repair their own errors and being given explanation on the correct form indicate students' willingness to save face while they make error during their oral presentation and at the same time expect for delayed explanation from the teacher so they can be sure how to correct their error for the future presentation.

The third preferred type of feedback in English speaking is elicitation, that is, when the teacher drew out students' error and asked them to provide the correct for. Preference to this type of feedback is because students felt they were given chance to 'activate [their] existing knowledge'. Similar to metalinguistic feedback, elicitation gives students more freedom to self correct and seems to enable them to save face.

The least preferred type of feedback in English speaking is recast when the teacher reformulated all parts of students' utterance consisting error. The unpopularity of this type of feedback is because the students 'felt confused and did not notice which one is the error'. During an interview a student reflected that "when the teacher corrected it (what she meant is her error in speaking) I just repeated what she said and I could not remember which one was wrong'.

These findings on students' preference toward feedback in speaking highlight two things. First, the students prefer to be given explicit explanation toward their errors. This will enable them to better understand their errors and how to correct them. Second, while doing oral production, they prefer to be given delayed feedback so they can first activate what their knowledge and have the chance to first self correct their own error.

Data on students' preference toward feedback in English writing shows that mostly the students prefer to get grammar correction $(72 \%)$ and content $(73 \%)$. In terms of the types of feedback, the students are also evenly divided between corrective feedback $(77 \%)$ and suggestion $(71 \%)$ with the least preference on criticism (11\%). To the extent of student's preference toward suggestion, finding from this current research agree with that of finding from previous studies that students prefer suggestion for the improvement of their writing. Response to open ended questionnaire show that suggestion informs the students the solution to their problem or error in writing $(54 \%)$. Suggestion also helps students to improve their English writing $(23 \%)$. This finding confirms that suggestion brings improvement on students' language production. Similar to suggestion, $82 \%$ of the students reflected that corrective feedback, particularly that of grammatical errors, help students identify and learn what is inappropriate and what is correct. That is to say that correction does help students to make revision. The least preferred type of feedback in English writing, criticism, was considered as 
making the students lazy (30\% responses) and even causing students to feel annoyed (37\%). This is because when given negative comments the students felt that they could not write and that their efforts were not appreciated.

Data on the types of teachers' feedback and students' preference in oral and written English show that although students prefer to be given feedback related to grammatical errors in both skills, there are different students' preferences toward the types of between the two skills.

\section{CONCLUSION}

The feedback mostly given by teacher in speaking class is corrective feedback with explicit correction particularly in grammar while survey on student preference show that student mainly prefer to be given opportunity to identify their own errors and try to think about the possible correct form of the error they have made. The feedback given by the teacher in written class is also corrective feedback particularly on sentence structure and grammar. While in speaking class student prefer to be give more freedom to correct their own error, student in writing class prefer to be given straight corrective feedback. Hence, the feedback given by the teacher is also the feedback preferred by the students. Teachers tend to give corrective feedback both in speaking and writing class. Student's have different preference on the types of feedback given by the teacher. They prefer metalinguistic feedback that allows them to think about their errors and the correct form in their learning to speak. However, students prefer to be give corrective feedback on their writing. These differences may relate to the variables of the teacher and school but such a different may also reflect that different skills may need different type of feedback.

\section{ACKNOWLEDGMENT}

The paper is developed from a collaborative research project conducted by the writers and Ainun Nisfuroh.

\section{REFERENCES}

[1] J. Harmer. The practice of English language teaching (3rd ed.), 2003. Edinburg: Longman.

[2] I.S., Calsiyao. (2015). Corrective feedback in classroom: Oral errors among Kaling -Apayao state college student. International Journal of Social Science and Humanities Research , 31, 394.

[3] K. Hyland \& F. Hyland, Feedback on second language students' writing, 2006, in Language Teaching, vol 39 no 2, 83-101.

[4] Ellis, R. (2009). Corrective Feedback and Lecturer Development. L2 Journal , 1 (1), 3.

[5] J. Muncie, Using written teacher feedback in EFL composition classes, in ELT Journal, vol 54 no. 1, 1999, 52.

[6] D. Hartono. (2012). Corrective feedback and their impacts to learners' uptakes in EFL speaking class. EDUCAFL, 10.

[7] M. Nemati \& M. Taghizadeh. (2013). Exploring similarities and differences between L1 and L2. International Research Journal of Applied and Basic Sciences , 4 (9), 2477-2492.

[8] S. Nancy. (1982). Responding to student writing . College Composition and Communication , 33 (2), 156
[9] R. Saputra. (2016). The effectiveness of using indirect feedback on students' writing of procedure text. Jakarta: UIN Syarif Hidayatullah.

[10] J. Russell, \& N. Spada. (2006). Synthesizing research on language learning and teaching. (Amsterdam : John Benjamins).

[11] C. Brandt. (2008).Integrating feedback and reflection in teacher preparation. ELT Journal, 62 (1), 40.

[12] F. Laila. (2011). The use of peer feedback to improve writing ability through facebook . Bachelor Thesis. Surabaya: UIN Sunan Ampel.

[13] D. Iryanti. (2015). The effectiveness of pPeer feedback in improving students' writing. Bachelor Thesis.Jakarta: UIN Syarif Hidayatullah

[14] D. Iryanti. (2015). The effectiveness of peer feedback in improving students' writing achievement. Bachelor Thesis. Jakarta: Syarif Hidayatullah State Islamic University.

[15] R. Silver \& S. Lee. (2007). What does it take to make a change? Teacher feedback and student revisions. English teaching: Practice and critique.

[16] J. Hattie \& H. Timperley. The power of feedback. Review Educational Research, 77 (1), 81-112

[17] K. Sambell. (2010). Rethinking feedback in higher education. Northumbria University: The Higher Education Academy.

[18] R. Sutton \& M.H. Karen Douglas. (2011). Feedback in schools. New York: Peter Lang Publishing

[19] L. Roy \& L. Ranta. (1997). Corrective feedback and learner uptake. SSLA, 20, 37-66

[20] J. Brophy. (1981). Teacher praise: a functional analysis. Review of Educational Reseach. 51 (1). 5-32

[21] F. Hyland \& K. Hyland. ((2001). Sugaring the pill: Praise and criticism in written feedback. Journal of Second Language Writing. 10 (3), 183-212

[22] J. Bitchener \& U. Knoch. (2008). The value of written corrective feedback for migrant and international students. Language Teaching Research, 12 (3), 410

[23] P.M. Lightbown \& N. Spada. (2006). How language are learned ( $3^{\text {rd }}$ edn). Oxford : Oxford University Press.

[24] D. Guenette (2007). Is feedback pedagogically correct? Research design issues in studies of feedback on writing. Journal of Second Language Writing, 16 (1), 50.

[25] D. Ferris \& B. Roberts. (2001). Error feedback in L2 writing classes. How explicit does it need to be? Journal of Second Language Writing, 10.

[26] R. Razali \& R. Jupri. (2014). Exporing teacher written feedback and student revisions on ESL student's writing. Journal of Humanities and social science, 19 (5), 67

[27] R. Yoshida. (2010). Teacher's choice and learner's preference of corrective feedback types. Language Awareness, 17 (1), 78-93

[28] P. Safari. (2013). A descriptive study on corrective feedback and learners' uptake during interactions in a communicative EFL class. Theory and Practice in Language Studies, 3 (7), 1165-1175

[29] A.A. Jabbari, A.M. Fazilatfar. (2012). "The Role of Error Types and Feedback in Iranian EFL Classrooms" International Journal of English Linguistics Vol.2, No.1, 135-148.

[30] K. Hetrakul. (2016). The second language. International Journal of Humanities and Social Science Invention, 5 (12), 96.

[31] M.F. Aranguiz \& A. Quintanilla. (2016). Oral corrective feedback strategies in EFL. ELIA, http://dx.doi.org/10.12795/elia.2016.i16.05

[32] J. Y. Yong. Learner English: A teacher's guide to interference and other problems (New York: Cambridge University Press, 2001). 281 
[33] M.P.A. Llach (2007). Lexical errors in young EFL learners: How do they relate to proficiency measures? Interlinguistica, (17), 63-73

[34] A. Razavi \& M. Naghizadeh. (2014). Corrective feedback in speaking in relation to error types in Iranian EFL classroom. International Journal of Emerging Investigation in Applied and Basic Sciences, 1 (1), 148-160

[35] U.T. Utami. (2012). Improving students' writing through teacher direct feedback in SMAN 1 Jogonalan. Thesis. Yogyakarta: Yogyakarta State University.

[36] A.M. Sholahuddin. (2014). Students' feedback in paragraph writing class of English Education Department. Surabaya: UIN Sunan Ampel Surabaya

[37] D. Nunan. (1991). Language teaching metodology: A textbook for teacher. New York: Prentice Hall

[38] R. Lyster \& L. RAnta. (1997). Corrective feedback and learner uptake. Cambridge: Cambridge University Press 